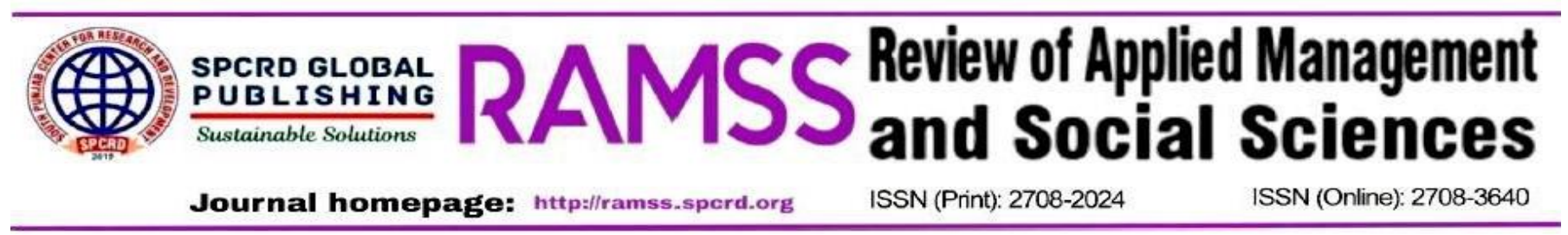

\title{
Image of Muslim Women and Media Discursivity: A Case Study of the Washington Post's Discourses
}

\author{
${ }^{\text {a }}$ Fatima Farooq, ${ }^{b}$ Muhammad Akbar Sajid, ${ }^{c}$ Fasiha Maryam \\ ${ }^{\text {a }}$ Lecturer Department of English NUML, Multan, Pakistan \\ ${ }^{\mathrm{b}}$ HOD, Department of English NUML, Multan, Pakistan \\ Email: masajid@numl.edu.pk \\ ${ }^{\mathrm{c}}$ Lecturer Department of English NUML, Mulan, Pakistan \\ Email: fmaryam@numl.edu.pk
}

\begin{tabular}{|c|c|}
\hline ARTICLE DETAILS & \multirow{9}{*}{$\begin{array}{l}\text { ABSTRACT } \\
\text { Print media representation about Islam and Muslims has never been } \\
\text { ideology free especially post 9/11. A war of words has ever been there } \\
\text { between non-Muslim west and Muslims. The dichotomy of Otherisation } \\
\text { divides the world into two poles i.e. good vs. evil. Similarly, the present } \\
\text { research critically decodes discourse of articles published in an American } \\
\text { newspaper i.e. 'The Washington Post' about representation of Muslim } \\
\text { women. The data has been collected from the newspapers' articles which } \\
\text { appeared from June } 2019 \text { to December 2019. The study employs } \\
\text { Fairclough's (1993) model of Critical Discourse Analysis. The analytical } \\
\text { categories of the mentioned model include representation, metaphor, } \\
\text { lexicalization, back/fore grounding, in/out group and number game. The } \\
\text { data has been analysed at the levels of word, sentence and discourse. The } \\
\text { analysis of the data reveals that Muslim women are represented } \\
\text { stereotypically through the discourse of the articles of the mentioned } \\
\text { newspaper as oppressed, narrow minded, hijabbed, and deviation from } \\
\text { norm. Moreover, according to western perception and representation of } \\
\text { this American newspaper they are contriving to harm civilized West by } \\
\text { introducing new system of caliphate to disturb the activities of civilized } \\
\text { world. The study concludes that print media discourses act as distorting } \\
\text { prism to represent a desired version of reality about Islam and Muslim } \\
\text { women to shape the mindset of the target audience accordingly. }\end{array}$} \\
\hline History: & \\
\hline Accepted 10 Mar & \\
\hline Available Online March 2021 & \\
\hline Keywords: & \\
\hline Islam, Muslim Woman, & \\
\hline Representation, CDA, Print Media & \\
\hline $\begin{array}{l}\text { JEL Classification: } \\
L 82, L 89\end{array}$ & \\
\hline DOI: $10.47067 /$ ramss.v4i1.105 & \\
\hline
\end{tabular}

(C) 2021 The authors. Published by SPCRD Global Publishing. This is an open-access article under the Creative Commons Attribution-

NonCommercial 4.0

Corresponding author's email address: masajid@numl.edu.pk

\section{Introduction}

Newspapers' articles mirror the ideological stance of a particular newspaper. They reveal socio- political scenario of a country and a particular context. One can know subjective/objective 
approach of a controlling ideological group through the analysis of the articles and the themes they carry. Media Discursivity has become one of the strongest discursive tools to propagate desired version of reality to the masses. They set the pulse of community and has power to influence decision makers and sway public opinion. They are analysis of important Happening or a subject that has cropped up all of sudden in the society and has become somewhat controversial.

Sajid (2012) contends that print media representation of Islam and Muslims has increased many fold post 9/11. Discoursal war is going on both sides for otherisation. Highly polarized discourses are coined and disseminated to represent the others negatively. He argues that print media discourses of the west are shaping the minds of the target audience accordingly by associating negativity with Islam and Muslims with the help of fear-based discourses. Similarly, the articles of the Washington Post which appeared during the mentioned time span contain fear- based representation of Muslim women. This has been done by employing various discursive moves.

The study answers the following research questions:

- How have Muslim women been represented discursively through the articles of The Washington Post published from June 2019 to December 2019 (daily)?

\section{Litrature Review}

Cherry's (2020) research on the othering of Muslim through electronic discourses reveals that media discourses are highly polarized and serve the interests of a particular group. The dichotomy of in and out- group is highlighted deliberately to position in- group positively and vice versa. Tahir (2013) asserted that textbooks are powerful ideological tools in the production and dissemination of us and them dichotomy. He contends that religious ideology imparted through textbook discourses goes a long in shaping the beliefs of the readers. Moreover the study concluded that religion is mostly state controlled, which negates the ideology that state has nothing to do with an individual's religion. Minorities everywhere are represented as others in terms of their religious affiliation. Similarly, Kassaye, Ashur and Heelsum (2016) argue that war of words has become a common phenomenon between Muslims and non- Muslim west for positive self and negative other representation. Competing discourses are coined tactfully to persuade the audience and to win their consent.

Silva (2020) argues that media conceptualization of radicalization which was denoted political and economic differences have now shifted to overwhelming and focuses on Islam. Most after it is observed that Islam and Muslims are targeted to discriminate a desired version of reality. This is done deliberately to associate negative attributes to Muslim men and women. In this way with the help of logically loaded discourses Muslim men are represented as violent and Muslim women are oppressed and mysterious. Powell (2017) opines that Othering the others negatively is not absolute rather dynamic process. This has become a frequent phenomenon among non-Muslim Western scholars in order to represent Islam as a violent religion and Muslims as hardliners only because of violent ideologies of Islam. In this way the concept of linguistic and social othering is played up at all levels. The frequent use of us vs. them dichotomy is continuity of a planned activity to target Islam and Muslim men and women.

\section{Methodology}

The present research employs Fairclough's (1993) model of critical discourse analysis which focuses on in-depth ideological analysis of language to explore embedded ideologies. He argues that 
language is everywhere in action in society and is capable of making the people behave in a desired manner. It is used as an insidious weapon to represent the people belonging in-group positively and vice versa. It is argued that print media discourses play a significant role in the dissemination of desired ideology to the target readers to hegemonise their minds. CDA intends to explore how social and political dominance is secured by one group over another. According to Fowler and Kress (1979) different possibilities of naming signify different assessments by the speaker/writer of his or her relationship with the person referred to or spoken to. Fairclough's (1993) stresses the ideological significance of lexical choices and argues that writer's choice of wording depicts the relationship between Us and Them. It helps to unlock the hidden ideologies in the linguistic respective of writer. The analytical categories employed in the study include lexicalization. Representation, metaphor, number game, back grounding and fore grounding. The main aim of discourse analysis is to analyze language and function of language in its social context. Thus, language is "irreducibly" a social practice (Kress and Hodge, 1993, p.202). Hence, the articles which appeared in the Washington Post during the mentioned time period have been analyzed using the above mentioned model to show how various linguistic devices are used by the Western print media to represent Muslims women as "Others".

\section{Analysis}

Thomas and wareing (2001) argue that language shapes people's perception about certain issues and consequently people start behaving like wise. Prevailing tendencies around us are reflected through print media discourses. Similarly, the concept of caliphate in Islam has been associated with Muslim women through the discourses of this newspaper's articles as a danger to civilized world (western world). Previously it was believed that Muslim men have been creating terror for the west. One of themes which emerged from the categorization of the articles was to highlight the activities of Muslim women in a Syrian camp promoting the Concept of caliphate among their fellow women. According to western perception and representation of Islam and Muslim women, this act may increase violence for the west. Therefore, Muslin women have been represented stereotypically by labelling them as new danger. The following chunks selected from the data illustrate the same concept.

\section{'The Islamic state is building caliphate in a Syrian camp' (August 16, 2019) "The united states and Europe must immediately address this urgent national security and humanitarian crisis, before a new caliphate is established while we watch".}

Fairclough (1989) argues that discursive tools used to represent some one highlight the sociopolitical between the representer and the represented. The textual reference mentioned above reveals western perception about muslin women. It is not only a threat to the U.S.A but also for all the European nations. The use of modal verb "must" represents degree of certainty and the amount of stress being laid on the issue created by Muslim women there in Syrian Camp. The use of adjective 'urgent' connotes that some sort of evil activities are going on which require immediate action. It also implies that there is a state of emergency in Europe because of the very activities being done by the Muslim women there in the camp. It has resulted in serious threat to their national security. Unless it is taken seriously, it may destroy The U.S.A and Europe. The U.S.A is meant for restoring peace in the world. This crisis has been created by Muslim women driven by violent Islamic ideology. Moreover, the adverb of time 'new' implies that the concept of caliphate has been very much prominent/ prevalent in Islamic society and from which the west is terribly afraid of. This concept 
has causing danger for the west when it was only followed by Muslim men, but the way it is prevailing among Muslim women it is going to be another threat. This justifies the use of adverb "new" This is how the Muslims as a whole have been represented as dangerous others through the discourse of the articles

The very mentioning of "humanitarian crisis" connotes that the Muslims following violent ideology and fundamentals of their religion have been involved in creating number of crisis and the prevailing concept of caliphates among women is a continuity of a tradition. In this way, with the help of loaded discourses of the mentioned newspaper articles, the dichotomy of good vs. evil has been played up.

Fairclough (2003) opines that a war of words is going on between non-Muslim west and the Muslims to position each other stereotypically. Especially Post-9/11 print media discourses of the mentioned newspapers have been representing Islam and Muslims derogatory by associating the concept of fundamentalism, rigidity, violence and threat to the Muslims. Competing discourses have been a significant feature of print media same event is perceived and represented differently by different ideological groups. Similarly the concept of Caliphate among Muslim men and women have been highlighted negatively. The same concept is interpreted in accordance with Muslim's ideology. It implies that it is meant to unite the people to bring unity, equality and justice in the society. But on the other hand the way it is perceived by the west is that it will create the crisis for the humanity. So, this is how the concept of competing discourses is there and the concept of 'us vs. them' is played up. The Muslims who try to revive their history have been labeled as one who are creating crisis for the civilized human being i.e. west. This is how print media discourse serves as a distorting prism because it represents the desired and constructed version of reality. Highly loaded lexical items have been used to disseminate a desired version of reality among the target audience. In this way people start believing what is made available to them through print media discourses. The discourse of the articles under analysis illustrates the same thing by associating negative attributes with Muslim women in general and the Muslim women in the Syrian Camp in particular. The text under analysis implies that Muslim women are also turning to be breeding ground of terror for the west. According to western perception, in the past mostly violent activities were associated with Muslim men but now the new trouble has arisen for the west in the form of establishing camps and reviving the concept of Caliphate among women as well. This has been represented by employing fear-based discourses in the selected articles. Another example about the Muslim women as deviant from the norm is as under:

\section{"Islamic state women have created a morality police corps inside the camp, enforcing sharia law and even conducting brutal execution".}

Fairclough (2006) argues that media discourses are best sight for ideological investment and power behind discourses plays a pivotal role in the propagation of dominant ideology in a subtle way. Similarly, the chunk from the data illustrates that there is more of violence in Islam. Therefore, its followers (either men or women) are more inclined towards exercising violence. The use of the verb "force' in its "ing form" implies that it is a continuous process in Islam and its followers are doing the same. The lines under analysis connote that Muslim women are imposing their selfrighteous fundamentals on the others.

Fairclough (1989) asserts that in media discourses everything is said against something 
unsaid. Similar trick has been played linguistically here as well. The organization of morality corps inside the camp implicitly highlight that Muslim women present in the camp are unaware of what morality is and therefore, this police has been introduced. Because of violent activities Muslim women need police to police themselves. Moreover, it is also mentioned here that most of the Muslims are forced to follow "sharia laws" and the violators are treated brutally by the rigid theologians. This is how print media discourses are used as an insidious weapon to represent Muslim women stereotypically.

Similarly, the activities done by the Muslim women in the camp to organize themselves has been represented as 'brutal execution'. The use of this expression is meant to exclude Muslims from civilization to associate brutality and violence with them. This is not accidental rather a deliberate attempt on the part of the writer of this particular article to link Islam and its followers with inhuman attributes. Therefore, the efforts made by Muslim women to revive Islamic values along with their men have been named as mini-caliphate. This is how politics is done with the help of language. The use of adjective "mini" with caliphate is derogatory and women's acts are being belittled. Similarly we find another example of negative representation of Muslim women when they are associated with so called terrorist and Jihadist organization ISIS. The western media perceived that whatever the activities are being carried out by Muslim women there in Syria and in the western countries they are fertile recruiting ground for ISSI. At surface level it seems that Muslims women are doing something for the betterment of their society and for themselves but actually this is how they train the Jihadists and rigid people to vent violence over humanity. Besides, we find another example where the western fighters have been segregated with Islamic fighters. So, the fighting for noble cause has always been associated with the west and if the same practice is done by the Muslims, it is represented by derogatory adjectives like fundamentalists, hardliners and rigid. All such words carry negative connotations. In this way lexicalization is so significant in positioning someone as belonging to in/out-group.

Fairclough (2000) opines that newspapers discourses create subjects qualitatively and quantitatively because there is a large readership of the newspaper and the people internalize what is made available to them through the discourses of newspapers. The way readership of this particular newspaper is increasing day by day, the more and more minds are shaped accordingly. This justifies his claim that whatever appears in print media is never ideology free. This is how print media discourses work qualitatively and quantitatively. Another important linguistic spin which has been used hare is the use of number game technique in the form of ' $100 \%$ '. This technique leaves nothing unclear about the person or thing under discussion. In the same way the western presupposition about Islam and Muslims has been propagated here. It illustrates western perception that the way Muslim women are doing their in Syria will lead to destruction for the civilized humanity. Here the use of number game technique has been employed to represent Islam and Muslim women negatively.

Moreover, the use of expression 'Islamic state fighters' is another technique of otherisation between Muslims and west. The use of adjective Islamic with the noun fighters others the Muslim fighters negatively. What it implies is that the western armed forces are fighting for the noble cause whereas, the Muslim fighters are terror for the civilized world (the west). On one hand the Muslim men are being represented as violent and hardliners and on the other Muslims women are being marginalized from the main stream. The use of expressions such as 'enforcing Sharia Law' and 'conducting brutal execution' shows the violent nature of Islam and Muslim. It conveys the message 
that sharia Law is something that is imposed and violators are punished. The use of 'ing' participle with verb 'enforce' implies that imposing violence from the Muslims is an ongoing phenomenon in the Muslim world. The use of discursive techniques employed in the selected data highlights the western mindset to represent Islam and Muslims stereotypically. Implied message propagated is to associate Muslims with violence and to disseminate the desired version of reality before the world.

Fairclough (2012) asserts that media language represents social critique and in order to decode discourses one not only requires linguistic competence but also Marxist and normative competence. He argues that economy shapes and raptures our social values. On the basis of economic conditions people are placed either as in/out- group. Similarly, Syria has been represented as banana republic which has specified a certain amount of money for the violent activities against others. The text of the article implies that the policies imposed on the Muslims by banana republic are unpleasant to the citizens. The following textual reference illustrates the same idea.

\section{Banana republic is selling hijab. \\ Muslim shoppers wonder: is it inclusion or appropriation? August 1, 2019 [The Washington post]}

Fairclough (2003) argues that language assigns identity to its users and certain stereotypes are associated to a particular group of people. Similarly, Hijab which is a part of Islamic dress code is perceived negatively in the western world. The Muslim women observing this dress code (hijab) are marginalized and are taken as oppressed, suppressed, mysterious and potentially terrorists and hiding something mysterious. This is how a new trend is there that not only Muslim men have been represented negatively by using adjectives of negative connotation for them, but also the Muslim women find such representation through print media discourses.

Fairclough (1989) opines that media discourses are layered and carry bundle of interpretations. Similarly, at surface level the constructed version of reality that is disseminated to the general masses is that religion is a private affair of an individual and state has nothing to do with it, but what happens is otherwise. One of the articles mentioned below contains same ideology and highlights the difference between appearance and reality.

\section{"Muslim Woman says in lawsuit that Falls Church Company wouldn't hire her because she wanted to pray at work" (The Washington post Sep 27,2019)}

The lines under analysis exposes the dual standard of the west that mostly Muslims are labelled as rigid and fundamentalist but here the story is otherwise. Observing prayer in break time must not be banned. Such things can be if the ethics of work place are violated. But marginalizing the Muslims ladies on observing religious dress code and saying prayer during off time shows western bias attitude toward Islam and Muslims. Hiring for a certain job should be based on merit criterion rather than on religious identities. Sometimes the Muslim women who observe parda are laughed at publically and at work places as well.

\section{"Am I really being made fun of for my religion in public in what's supposed to be professional workplace?”}

It connotes that the Muslims in the west are negatively Othered and are unduly deprived of 
the opportunities. The use of first person pronoun ' $I$ ' implies degree of certainty on the part of the oppressed. Moreover, the use of the expression made fun of represent cynic attitude of the west towards the Muslims. The lexical item used to represent Islam and Muslims in the selected data illustrates that through the ideologically loaded language the controlling media group wants to propagate negative image of Muslim women to the masses to shape their minds accordingly.

\section{Conclusion}

The analysis of data reveals that media discourses serve as distorted prism to disseminate a desired version of constructed reality about Islam and Muslims. The dominant themes which emerge in the present research are concept of caliphate and its revival among the Muslims and especially among Muslim women. The way Muslim women have mobilized themselves there is Syria and other part of Muslim world is perceived as a threat to western world. The revival of caliphate among Muslims I meant to assist their males and to reorganize the Muslim organizations to promote and implement Sharia laws in the Muslim countries but it has been propagated negatively by using derogatory language to shape the mindset of target readers accordingly. Similarly the findings of the research reveal that the act of wearing Hijab/Pardah by some of the Muslim ladies there in the west is taken as a symbol of oppression separation and marginalization. Besides, the research concludes that negative othering of Muslim women at work place has become a common phenomenon among the liberal west to propagate anti-Islam ideology. The insidious weapon on language is deliberately manipulated in this regard. Vocabulary of power and adjective carrying negative connotations have been used to propagate negative image of Muslim women through the discourses of the Washington Post.

\section{References}

Fairclough, N. (1989). Language and Power. Harlow: Longman.

Fairclough, N. (1993). Critical discourse analysis and the marketization of public discourse: The universities. Discourse and Society, 4(2), 133-168.

Fairclough, N. (2000). Language and Power. London: Longman.

Kamppi, Creutz, Karin (2008) The Othering of Islam in a European Context Polarizing Discourses in Swedish-Language Dailies in Finland

Kassaye, A., Ashur, I. \& Heelsum, A. (2016). The relationship Between Media Discourses and Experiences of Belonging. Ethnicities. 16, 773-797

Kress, G. \& Hodge, B. (1993). Language an Ideology. London: Routledge and Kegan Paul.

Linda .T. \& Wareing.S .(2001). Language, Society and Power. London and New York.

Powell, J. (2017). Us vs them: the sinister techniques of 'Othering'-and how to avoid them. The Guardian, 8.

Spivak, G. (1987). In Other Worlds: Essays in Cultural Politics. Taylor and Francis.

Tahir, M. (2013). A critical discourse analysis of religious othering of Muslim in the Washington Post. Middle East Journal of scientific research. 14, 744-753

Fowler.R .Kress(1979).Critical Linguistics.London:Routledge,Keeganpaul

Fairclough, N. (2000). Language and Power. London: Longman.

Fairclough, N. (2003). Analysing Discourse: Textual Analysis for Social Research. London: Routledge.

Silva, Derek .( 2017). "The Othering of Muslims: Discourses of Radicalization in the New York Times, 19692014." Sociological Forum 32(1):138-61.

Fairclough, I, Fairclough, N (2012). Political Discourse Analysis: A Method for Advanced Students. London: Routledge. 